\title{
Inventing Metallurgy in Western Eurasia: a Look Through the Microscope Lens
}

\author{
M. Radivojević
}

\begin{abstract}
The quest for the 'when' and 'where' of the world's earliest metallurgy has been dominating scholarly research on this topic for decades. This paper looks beyond the question of origins by discussing 'how' and 'why' metallurgy was invented. It looks into choices and skills involved in selection, experimentation and processing of distinctively coloured copper minerals and ores throughout c. 2000 years in the Balkans. The body of evidence is built around the currently earliest evidence for copper smelting, dated at c. 5000 ВС and discovered in the Serbian Vinča culture site of Belovode. The 'microstructure' of a metal invention process is explored through optical and compositional analyses of a selection of copper minerals and metal production evidence: ores, slags, slagged sherds and metal droplets recovered from seven settlements in Serbia and Bosnia and Herzegovina, altogether dated between the late seventh and the late fifth millennia $\mathbf{B C}$. This research suggests an independent technological trajectory of the emergence of metallurgy in the Balkans based on a unique technological meme, black and green mineral, which follows the evolution of early metallurgy from monoto polymetallic within the fifth millennium BC.
\end{abstract}

Pyrometallurgy is the first transformative technology in the history of humankind. Academic debates on the invention of metallurgy are dominated by the pursuit of the when and where of the earliest copper metal smelting event. The recent study of $c$. 7000-yearold copper smelting evidence from Belovode, a Vinča culture settlement in Serbia, revived the possibility of multiple, rather than single, origins of metallurgy in Eurasia (for opposing views, see Radivojević et al. 2010; Roberts et al. 2009). However, little has been done to address the invention of metallurgy beyond the discussion of its exact time and location.

The invention of metallurgy, like any other novel technology, must have evolved through accumulation of knowledge of the process components, which was built through experiments, recombination or reapplication (to a new purpose) over a period of several decades, or centuries (Basalla 1988; Lienhard 2006). Thus, it may have taken a few generations of craftspeople before the invention developed and sev- eral decades, or centuries, of the process evolution until it reached a form that functioned to a desired purpose. In archaeological records, inventions are hardly visible, and what archaeologists usually see is a mature form of technological innovation, already replicated within a population.

The 'visibility problem' of a technological invention can be successfully addressed by applying materials science methods to archaeology. Archaeometric studies have long been used to identify inventive and innovative technological skills at analytical scales invisible to the naked eye (e.g. Killick \& Fenn 2012; Martinón-Torres \& Rehren 2008; 2009; Tite et al. 2001). They also emphasize the importance of understanding the interaction of environment, physical properties of materials and social practices involved in their manufacture (see the concept of 'embedded technologies' in Sillar \& Tite 2000). However, although these factors form an important part of an invention interpretation and explanation, this study will limit its focus to

Cambridge Archaeological Journal 25:1,321-338 $\quad$ C 2015 McDonald Institute for Archaeological Research. The online version of this article is published within an Open Access environment subject to the conditions of the Creative Commons Attribution licence http://creativecommons.org/licenses/by/3.0/ doi:10.1017/S0959774314001097 Received 16 Feb 2014; Accepted 17 Nov 2014; Revised 12 Nov 2014 
technological aspects surrounding the phenomenon of metal invention only and provide an in-depth analysis of the earliest metal-making recipes in western Eurasia. The aim of the study is to demonstrate the potential of such an approach as well as to contribute to our understanding of how and why metal emerges in this part of the world.

The $c .5 \mathrm{~g}$ of copper slag from the site of Belovode dated to c. 5000 BC and published in Radivojević et al. (2010) represent the earliest recorded copper production evidence in Eurasian metallurgy. This small assemblage attests the Balkans as one of the heartlands of Old World metallurgy, and stands out as unprecedented in size, quality and resolution when compared to potentially contemporaneous materials from three other potential heartlands of metallurgy: Anatolia; Iran; and Iberia (for discussion, see MurilloBarroso \& Montero-Ruíz 2012; Roberts \& Thornton 2014).

Importantly, the quantity of extant production evidence from the Balkans still stands in stark contrast to c. 4.7 tonnes of extant massive copper implements that circulated this area in the fifth millennium вс (Pernicka et al. 1997; Ryndina 2009). The unparalleled abundance of metal artefacts, similar technology of working and distinctive typological features prompted Chernykh (1978) to define the BalkanCarpathian region a metallurgical province, which influenced the beginnings of metallurgy north of the Black Sea region and beyond.

The aim of this paper is to look beyond the sensationalist discussions on the when and where of early metallurgy and discuss how and why metallurgy was invented, by investigating the evidence assembled from several Balkan Transitional/Early Neolithic and Early Chalcolithic Vinča culture settlements (c. 6200-4400 BC). It will also demonstrate the capacity of materials science in examining archaeometallurgical materials and interpreting the choices and skills involved in the selection, experimentation and processing of distinctively coloured copper ores throughout almost two millennia in the Balkans. The 'microstructure' of the metal invention process is revealed through optical and compositional analyses of a selection of copper minerals, ores, slags, slagged sherds and copper metal droplets uncovered from seven settlements: Lepenski Vir, Vlasac, Kolubara-Jaričište, Belovode, Vinča, Pločnik and Gornja Tuzla (Fig. 1), all dated between the late seventh and the late fifth millennia вс. This research suggests a unique and independent technological trajectory for the emergence of metallurgy in the Balkans and follows its evolution from mono- to polymetallic within this period.

\section{On techmemes and invention}

Technology, as much as culture, modifies through time, or, to put it in Darwin's words, 'descends with modification'. In principle, any system (living or not) can fit into this model if it is composed of a population of entities capable of multiplying and transmitting information with variable success (Jablonka \& Ziman 2000, 13-14; O'Brien \& Lyman 2000). The unit of cultural transmission is contained in the idea of a meme, which is shaped by various social mechanisms in addition to the forces of natural selection (Dawkins 1976; Shennan 2002). In technological environments, the concept of a technological meme (or techmeme) is understood to operate in the same way as a cultural meme does; it is technological information transmitted, stored or recombined by a wide variety of processes (Ziman 2000). The application of an evolutionary perspective in studying technology would therefore require the presence of three main properties in the matter of examination: technological entities must be prone to multiplying; they must vary; and some of the variation must be hereditary (cf. Jablonka \& Ziman 2000, 13).

Importantly, in studying the technological evolution of a particular invention, one must take into account technological constraints that derive from the world of physics and cannot be influenced by human agency only (Vincenti 2000). Technology, therefore, has its own dynamics as well as evolutionary potential, which can be related to pre-existing elements, but also triggered by various social, physical and ecological environments (cf. Roux 2003).

Invention has rarely been addressed in the archaeological record beyond modest statements commonly related to absolute dating. Usually, invention is seen as a complex creative act that underlies technological development and accounts for an individual's achievement, whether deliberate or by chance (Renfrew 1978; Torrence \& van der Leeuw 1989). The achievement may include a radically new product as much as a recombination of technological components in a novel manner (Weber et al. 1993). Alternatively, an invention may involve the application of an existing technology to a new purpose (Henrich 2010).

The evolutionary mechanisms that lie behind the inventive behaviour in humans have not been widely studied. The history of human invention is often compared to biological systems, since accidents and random findings appear to be more common than intentional ones (Fitzhugh 2001). However, changes in material culture are more likely to come through a build-up over a certain period, rather than as a radical technological breakthrough (Shennan 1989). The 


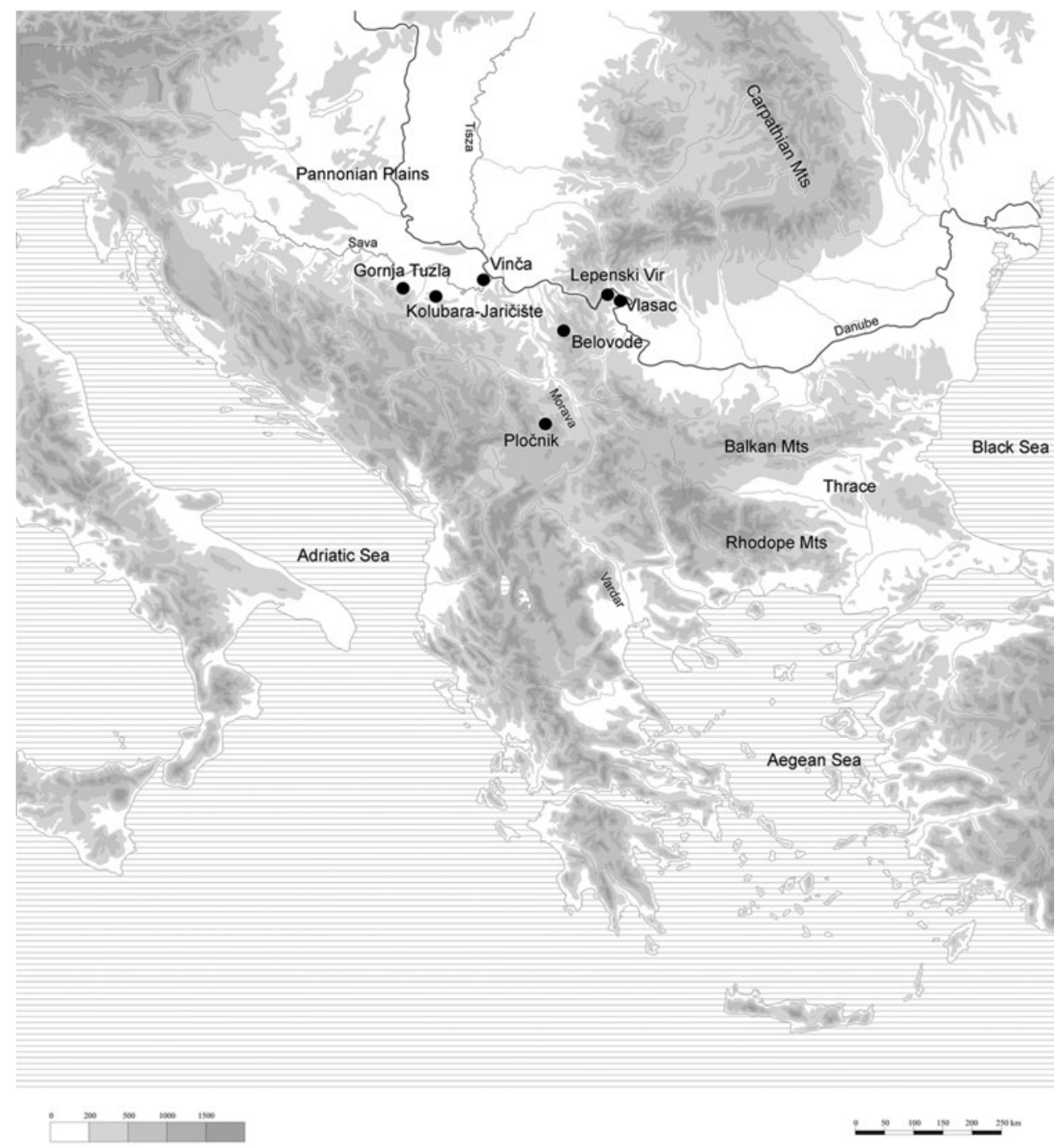

Figure 1. Map of studied sites. (Map courtesy of M. Milinković, Faculty of Philosophy, Belgrade.)

'eureka' moments usually arrive as the result of arduous work where, after a number of trials and errors in experiments, an inventor arrives at understanding of his or her discovery (David 2000; Kuhn 1962).

Why do people invent? Inventions capture environments in which inventors lived, and reflect various stimuli that stemmed from both exogenous and endogenous developments in their surroundings. For instance, the evolution of a particular tool may be driven by demands of the market, and as such result from adaptation and natural selection (Carlson 2000). Nonetheless, assuming that (market) demands are the sole forces of an invention overlooks the role of inventors and their vision of the target market, which may be very different from the actual marketplace.

Lienhard $(2006,118)$ advocates for four major forces that shape an invention: profit, necessity, plea- sure and freedom. Both profit and necessity may be categorized as exogenous forces in the process of invention. In his study on inventiveness, Fitzhugh (2001) draws on a popular idea that humans carry an inherent capacity to invent and adopt innovations under stressful conditions, which is captured by a famous phrase 'necessity is the mother of invention' (sensu Mason 1895). In his study on technological behaviour of the tribes in Alaska, he comes to the conclusion that individuals are more encouraged to inventive behaviour in times of economic or environmental uncertainty or strong competition. Such risk-innovative behaviour favours adopting new technology because it is seen as restoring certainty (Fitzhugh 2001, 135).

The factor of pleasure does not include stressful environments, but the ultimate satisfaction of a personal achievement. The forces of freedom in the evolution of invention, on the other hand, allow an 
inventor to break through the 'status quo' and express rebellion; these may include freedom from external prescription or freedom from 'mind chains'. To illustrate this point, Lienhard $(2006,118)$ argues that all great inventive epochs of the world have been marked by climates of increased personal liberty, as in the Hellenistic world or in Europe of the eighteenth century.

In contexts of fertile climates, simultaneous inventions emerge as particularly interesting topic, since the history of science contains a considerable number of inventions that have been made at roughly the same time by different investigators, apparently unaware of each other's work. Jewkes et al. $(1969,172)$ maintain that such a coincidence may be the case when environmental stimuli are similar enough to direct minds towards the same ends. However, to argue for separate inventions one needs to provide sufficient evidence for independent evolution of an idea, such as the presence of unique core traits that developed in a culture as unrelated to traits from other cultures in its surrounding (Steward 1955).

How do people invent? Lienhard $(2006,158)$ holds that there are three stages in the evolution of any technology: gestation, cradle and maturation. Gestation refers to a fairly long period preceding the moment when an invention takes an identifiable form. From the perspective of an inventor, it is a period when he or she commences serious work on creating a capability, without knowing what form it will take. Once invention emerges in a reasonably functional form, it enters the cradle stage. During the cradle period, the inventor seeks to understand the invention and alter it in ways that would make it serve a purpose. As soon as the invention reaches a form that is no longer dramatically changed, the maturation period begins.

The three stages in the evolution of invention very rarely take place during the lifetime of a single inventor. It could take a few generations of inventors who contribute to accumulation of knowledge before the invention is sufficiently perfected to find wider acceptance (Lienhard 2006, 165). These contributions are commonly mirrored in a high frequency of failure and unintended outcomes that occur over a period of uncertain length. For example, failed experiments, evidence for trial and/or design improvements of tested variables are ideally what one would investigate in an archaeological record. Therefore, biography of a past invention would often have started a couple of decades, or even centuries, before it became visible in the archaeological record. It is often the case that inventions cannot find any economic use until other ideas that are yet to be discovered render practical what once was thought a long shot (Wiener 1993, 145).
When an invention affects the evolution of the system and is successfully transmitted within a population, and beyond, it is recognized as an innovation (e.g. O'Brien \& Shennan 2010a; Renfrew 1978; van der Leeuw \& Torrence 1989). A technological innovation itself is not usually a monolithic entity only, but an 'amalgam of units', or a 'recipe' containing ingredients required to make an object $\left(\mathrm{O}^{\prime}\right.$ Brien \& Shennan $2010 \mathrm{~b})$, such as a metal axe. In a technological context, it is practically a 'to-do' list of what, how and when to make something, and for how long (Krause 1985). The ingredients may be rearranged to form a different recipe, and their combination is flexible towards improvization within and beyond an innovation-bearing society (O'Brien \& Shennan 2010b).

Studies in the transmission of crafts have shown that in traditional societies they are usually passed once in a lifetime from parent to the same gender offspring (i.e. vertical transmission) and rarely from peers (i.e. horizontal transmission) (Shennan \& Steele 1999). The likelihood of adopting a novelty is increased by the numbers of teachers to learners and their social relationships (Cavalli-Sforza \& Feldman 1981; Shennan 2000; 2001). This process works both ways: the accumulation of skills in a society may lead to population growth and vice versa; this emphasizes the role of demography as a powerful evolutionary mechanism for increasing or decreasing the probability of inventions that build on previous ones and for their maintenance through cultural transmission (Shennan 2001; Powell et al. 2009).

In sum, various social, environmental and physical processes affect the trajectory of a technological invention, which evolves with variable success through variation and replication via transmission mechanisms. The accumulation of technologically transmitted attributes (techmemes) over time triggers new inventions, which accordingly enter a new cycle of technological evolution. Figure 2 illustrates these points through a simplified representation of a lifecycle of a technological invention and innovation. The underlying technological information, the techmeme, which is transmitted and which varies and accumulates throughout this process, takes the central place in the described lifecycle.

My intention here is to explore the technological context of the invention of metallurgy in the Balkans by identifying variables (techmemes) in the metal production process and their evolutionary potential to replicate and recombine during the period under study, primarily from a technological point of view. Hence, physical constraints of the metal production process will be the primary focus of my approach for investigating the invention and subsequent 


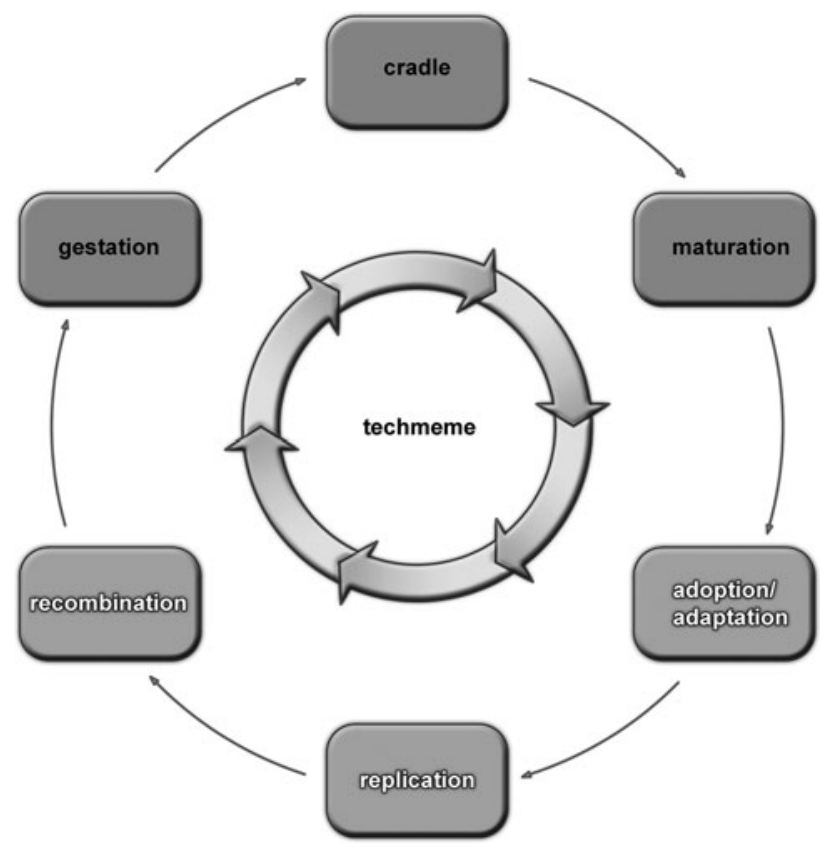

Figure 2. A lifecycle of technological invention and innovation. Three stages of invention: gestation; cradle; and maturation are followed by three stages of innovation: adoption/adaptation; replication; and recombination. The technological information, or the techmeme, is at the core of the entire process.

innovation of metal making in the Balkans. My aim is to demonstrate how technological analysis of the earliest archaeometallurgical debris can be used to address the very emergence of metallurgy in this region as well as to advance our fragmentary knowledge of the metal-producing communities at the time.

\section{Materials}

The study assemblage for this research comes from seven different sites in the Balkans (Fig. 1). I have selected black and green copper minerals coming from domestic contexts of three late seventh- to mid sixthmillennium вс occupations at the sites of Lepenski Vir, Vlasac and Kolubara-Jaričište (Borić \& Dimitrijević 2007, 51; Radivojević 2012) in order to explore copper selection practices predating the smelting activities in this area (Table 1). These black and green mineral lumps, unlike documented copper mineral beads from Lepenski Vir (Srejović 1972, 146), bear no traces of processing such as polishing or drilling. Interestingly, in the site of Vlasac, fist-sized lumps of these coloured minerals amount to an incredible 70 pieces discovered together within the Late
Mesolithic/Transitional phase at this site, and dated tentatively to c. 6200 вс (Srejović \& Letica 1970-1971; Borić et al. 2008, 277-9; Radivojević 2012, 116-17).

The remaining four sites (Belovode, Vinča, Pločnik and Gornja Tuzla) belong to the Late Neolithic/Early Chalcolithic Vinča culture phenomenon, dated between c. 5400 and c. 4600 вс (Borić 2009; Gornja Tuzla has one date only at c. 4400 BC, see Radivojević 2012, 150), and yielded various materials attesting both copper mineral use and archaeometallurgical activities during the designated period (Table 1). Archaeometallurgical materials in these sites usually occur during the Gradac Phase of the Vinča culture, starting c. 5000/4950 BC, and continue to appear in the excavation record until its end, at c. $4600 \mathrm{BC}$. The earliest occurrence of archaeometallurgical materials is recorded in Belovode at c. 5000 BC, followed by slag from the site of Vinča dated c. 4800 BC and the Gornja Tuzla slag documented just after the horizon (stratum) dated c. 4400 вс (Radivojević 2012, 119ff.). Copper mineral use appears throughout the entire sequence of this culture in all sites and in domestic contexts only. Their sampling procedure included both minerals preceding and associated with metallurgical activities in the Vinča culture sites, amounting to 13 samples in total presented here (Fig. 3; Table 1).

The rationale for separating copper mineral use from copper ore smelting is based on the type of activities undertaken during their processing. While 'cold' techniques are used to process copper minerals into pigments or beads, the 'hot' extraction of copper ores produces a different type of material and therefore yields a different kind of economic benefit (Radivojević et al. 2010, 2779). Thus, I will use the term 'mineral' throughout the text until analyses reveal which copper minerals were used as copper ores.

Archaeometallurgical materials in this study include slags, slagged sherds and copper metal droplets (Fig. 3; Table 1). Slag is a by-product of copper smelting that separates from metal during extraction, and is represented here by 10 green-stained and strongly magnetic droplets from the sites of Belovode and Vinča. Slagged sherds (5 in total, from Belovode and Gornja Tuzla) were most likely fragmented pottery pieces that lined a hole-in-the-ground and preserved some of the liquid slag spillage on them (Fig. 3). Two copper metal droplets (Belovode M6 and Pločnik 52) were initially mistaken for copper minerals; however, they were included in analysis after sectioning revealed their metallic structure. Importantly, Belovode M6 chronologically precedes the production debris from this settlement (Radivojević \& Kuzmanović-Cvetković forthcoming). All studied 
Table 1. Sampled materials description, context and chronology. Given the lack of directly dated contexts for all finds, the Vinča culture assemblage is presented through relative chronology, which in general absolute dates is as following: Vinča A starts at c. 5400/5300 BC, and Vinča B1 around 5200 ВС. The highest probability end for Vinča B1 is c. 5000/4950 ВC; this marks the beginning of the Gradac Phase (Vinča B2), which probably lasted for c. 50-100 years. Vinča C lasts from c. 4900 to c. 4850/4800 BC, while the end of Vinča D falls around 4650/4600 BC (Borić, 2009: 234).

\begin{tabular}{|c|c|c|c|c|c|}
\hline No. & Analytical No. & Type of Material & Field label & Field context & $\begin{array}{l}\text { Relative / absolute } \\
\text { chronology }\end{array}$ \\
\hline 1 & Lepenski Vir 1 & Copper mineral & 1967 excavations & House floor & $\begin{array}{l}\text { Transitional Phase/Early } \\
\text { Neolithic, c. } 5900 \text { вс }\end{array}$ \\
\hline 2 & Vlasac 2a & Copper mineral & Horizon III $(\mathbf{v} 0.9 \mathrm{~m})$ & Household & $\begin{array}{l}\text { Late Mesolithic/ } \\
\text { Transitional Phase, } \\
\text { c. } 6200 \text { BC }\end{array}$ \\
\hline 3 & Kolubara-Jaričište S16 & Copper mineral & Trench 54, unit 1.118 & Dwelling structure & $\begin{array}{l}\text { Late Starčevo, } c . \\
5600-5500 \text { вс }\end{array}$ \\
\hline 4 & Belovode 3 & Copper mineral & Trench 13 , spit 14 & Household & Vinča B1 \\
\hline 5 & Belovode M20 & Copper slag & Trench 3 , spit 2 & Waste pit & Gradac Phase \\
\hline 6 & Belovode M21 & Copper slag & Trench 3 , spit 4 & Waste pit & Gradac Phase \\
\hline 7,8 & Belovode M22 $(a, b)$ & Copper slag & Trench 3 , spit 5 & Waste pit & Gradac Phase \\
\hline 9 & Belovode M23 & Copper slag & Trench 3, spit 7 & Waste pit & Gradac Phase \\
\hline 10,11 & Belovode 30a, 30c & Slagged ceramic sherd & Trench 3 , spit 5 & Waste pit & Gradac Phase \\
\hline 12,13 & Belovode 31a, 31b & Slagged ceramic sherd & Trench 3, spit 6 & Waste pit & Gradac Phase \\
\hline 14 & Belovode 33b & Copper mineral & Trench 14 , spit 15 & Household & Vinča B1 \\
\hline 15 & Belovode 34a & Copper mineral & Trench 14 , spit 3 & $\begin{array}{l}\text { Household, in an } \\
\text { amphora }\end{array}$ & Gradac Phase \\
\hline 16 & Belovode 131 & Copper slag & Trench 3 , spit 6 & Waste pit & Gradac Phase \\
\hline 17 & Belovode 134 & Copper slag & Trench 3, spit 7 & Waste pit & Gradac Phase \\
\hline 18 & Belovode 136 & Copper slag & Trench 3 , spit 5 & Waste pit & Gradac Phase \\
\hline 19 & Belovode M6 & Copper metal droplet & Trench 3, spit 10 & Waste pit & Gradac Phase \\
\hline 20 & Belovode M10 & Copper mineral & Trench 3, spit 19 & Household & Vinča B1 \\
\hline 21 & Vinča 79 & Copper slag & Edm 95 & $\begin{array}{l}\text { Household, near a } \\
\text { fireplace }\end{array}$ & Vinča D1/D2 \\
\hline 22 & Vinča 91 & Copper slag & Edm 485 & $\begin{array}{l}\text { Within a (ritual?) } \\
\text { feature }\end{array}$ & Vinča D1/D2 \\
\hline 23 & Vinča 99 & Copper mineral & Edm 276 & $\begin{array}{l}\text { Household, near a } \\
\text { fireplace }\end{array}$ & Vinča D1/D2 \\
\hline 24 & Pločnik 51 & Copper mineral & Trench 19, spit 23 & Household & Vinča A \\
\hline 25 & Pločnik 52 & Copper metal droplet & Trench 14 , spit 10 & Household & Vinča B1 \\
\hline 26 & Pločnik 54m & Copper mineral & Trench 16 , spit 19 & Household & Vinča B1 \\
\hline 27 & Pločnik 57 & Copper mineral & Trench 19 , spit 13 & Household & Vinča B1 \\
\hline 28 & Pločnik 72m & Copper mineral & Trench 20, spit 3 & Workshop & Gradac Phase \\
\hline 29 & Pločnik 209 & Copper mineral & Trench 22 , spit 15 & Workshop & Vinča B1 \\
\hline 30 & Gornja Tuzla 182a & Slagged ceramic sherd & Trench II/1, stratum II & $\begin{array}{l}\text { Household, } \\
\text { charred wood }\end{array}$ & Vinča D \\
\hline
\end{tabular}

sites have also yielded (99 per cent pure) copper metal artefacts, including two tin bronze samples (Radivojević 2012, 327; Radivojević et al. 2013); these will be mentioned only in the pool of metal artefacts known from this period in the Balkans in the fifth millennium BC.

Thirty samples in total were studied in detail at the Wolfson Archaeological Science Laboratories at the UCL Institute of Archaeology. Analytical techniques and applied methodology are presented in Supplementary Materials.

\section{Copper minerals (c. 6200 BC-c. 4600 BC)}

Analyses of 13 copper minerals reveal two compositionally distinctive groups: oxidic and sulphidic minerals. However, together they form one colour-coded group, green and black/grey (Fig. 4). The oxidic minerals are more granular and black-and-green, which is a colour feature also detected under the microscope as two phases: bright green crystals (probably as carbonate) and grey oolithic structures, with strikingly similar copper and manganese content throughout 


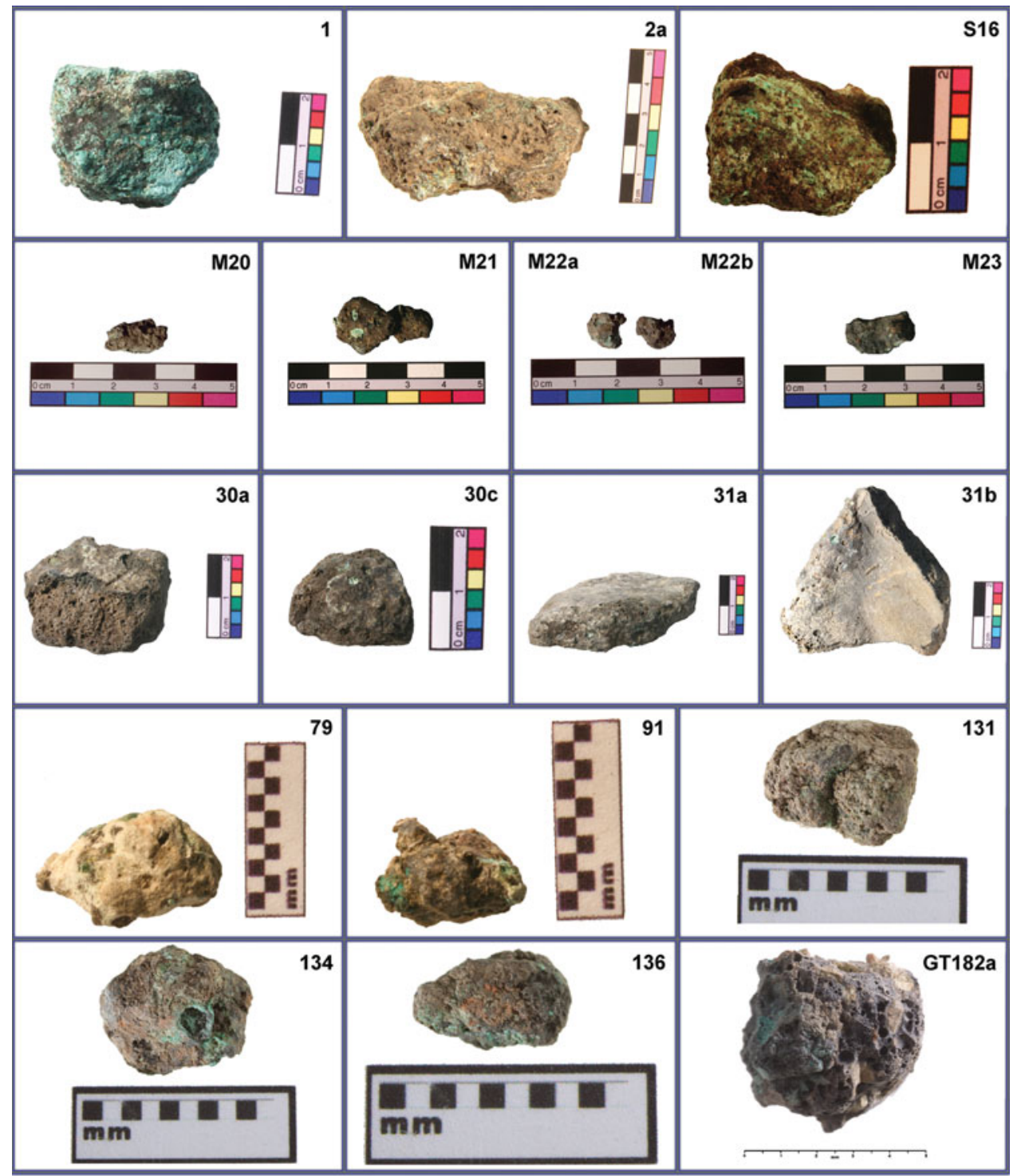

Figure 3. (Colour online) Copper minerals (Early Neolithic) and copper slags and slagged sherds (Vinča culture) studied here, with sample numbers in top right corner. Lepenski Vir 1 (copper mineral); Vlasac $2 a$ (copper mineral);

Kolubara-Jaričište S16 (copper mineral); Belovode M20, M21, M22a, M22b, M23, 131, 134 and 136 (free slag samples); Belovode 30a, 30c, 31a, 31b (slagged sherds); Vinča 79, 91 (free slag samples); and Gornja Tuzla 182a (fragment of a slagged sherd).

studied samples. The ratio of $\mathrm{Cu}$ to $\mathrm{Mn}$ varies from 1:1 to 2:1 in favour of copper (Table S2 in Supplementary Material) (Radivojević 2012,210). The observed values in the grey oolithic structures are plotted in a ternary diagram $\mathrm{MnO} / \mathrm{ZnO} / \mathrm{CuO}$ (Fig. 5), which illustrates remarkable compositional similarity of oolithic formations in minerals coming from all studied sites.

Three copper minerals in total were found to contain sulphur (Belovode 3, 33b and Pločnik 72m). In addition to copper oxide, these samples include phases compositionally closest to covellite (CuS, in 3 and $33 \mathrm{~b})$, chalcocite $\left(\mathrm{Cu}_{2} \mathrm{~S}\right.$, in $\left.72 \mathrm{~m}\right)$, pyrite $\left(\mathrm{FeS}_{2}\right.$, in $72 \mathrm{~m})$ and sphalerite $(\mathrm{Zn}(\mathrm{Fe}) \mathrm{S}$, in $72 \mathrm{~m})$. Macroscopically, these appear more solid than the black-andgreen oxidic minerals, although they too have distinctively coloured cross-sections in shades of green and grey, with metallic lustre (Fig. 4).

Microanalyses of copper minerals from seven different sites spanning c. 1600 years show that during this period a pattern of selecting manganeserich mineral batches can be observed. Their common 

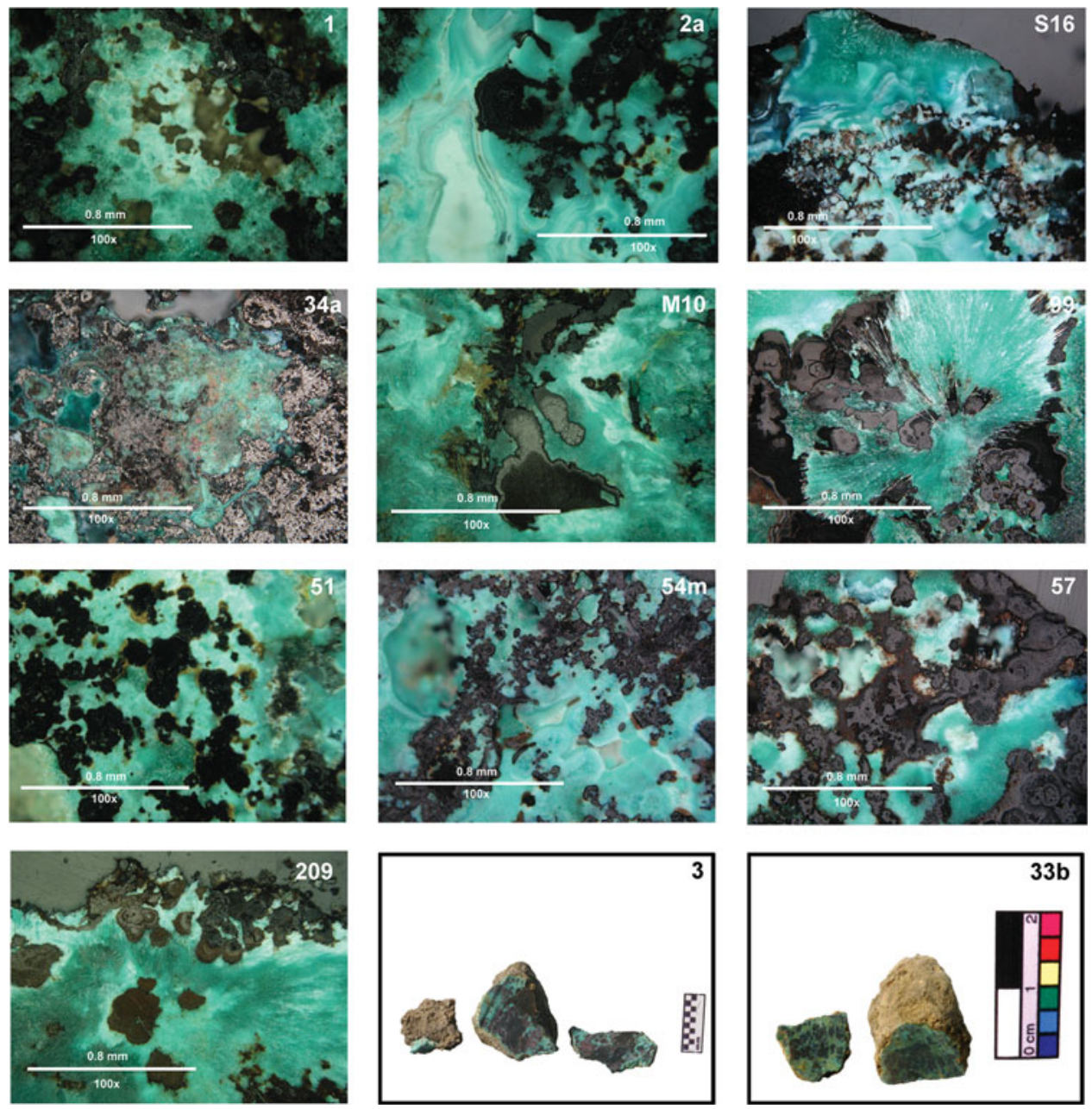

Figure 4. (Colour online) Photomicrographs of oxidic and sulphidic minerals studied here, under cross polarized light and with sample numbers on top right corner. Lepenski Vir 1; Vlasac 2a; Kolubara-Jaričište S16; Belovode 34a, M10; Vinča 99; Pločnik 51,54m, 57 and 209; Belovode 3 and 33b.

features are black and green appearance and similar composition, which is striking as a particular selection choice from the Early Neolithic until the end of the Vinča culture. These minerals were selected over others available in nature for technological and cultural reasons to be explored further in this research, and clearly indicate an awareness of their material properties throughout $c .1600$ years across the central Balkans.

Also, the presence of sulphidic copper minerals in the fifth-millennium вс Chalcolithic settlements is noteworthy, as it is rare and still not well documented in this period. Importantly, both oxidic and sulphidic copper minerals have distinctive colour patterns of green and black/grey, due to their manganese or sulphur content. It also implies that, at the very early stage of Balkan pyrometallurgy, copper smiths from Belovode and Pločnik were experimenting with dif- ferent kinds of black and green minerals, and that the outer appearance of these minerals played a significant role in the selection process.

\section{Production evidence (c. 5000 BC-c. 4400 BC)}

All Vinča culture copper slags (free slag samples and slagged masses on pottery sherds) present markedly similar macro- and microstructure of a slag matrix that solidified from a fully liquefied state. According to the fully molten state of copper metal prills embedded in studied samples, the working temperatures reached c. $1083^{\circ} \mathrm{C}$ (Fig. 6). The main constituents of slag matrices in these samples are silica, alumina, lime, iron and copper oxides, amounting to around 80 per cent on average, followed by elements mainly coming from fuels: phosphorus, potash and magnesia, which amount to another 5-13 wt per cent on average (Table 2). The 


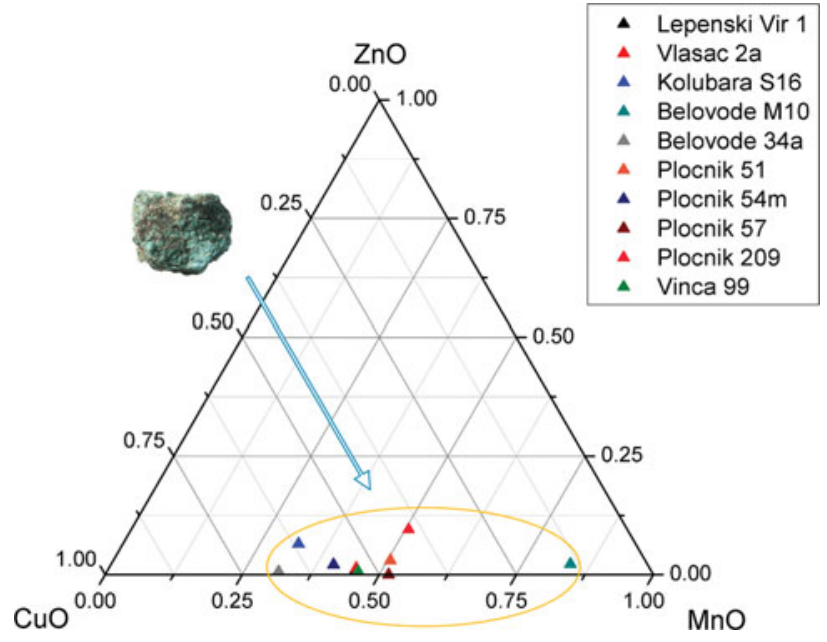

Figure 5. (Colour online) Ternary plot $\mathrm{MnO}-\mathrm{ZnO}-\mathrm{CuO}$ of the results obtained for oolithic structures in all oxidic (black and green) minerals presented here. Note their clustering around the middle of the $\mathrm{CuO}-\mathrm{MnO}$ axis, marking compositional similarity.

clearest indication that these slag glasses are not just fused ceramic bodies is the distinctive ore component: the slag matrices from Belovode and Vinča are rich in $\mathrm{MnO}$ and $\mathrm{ZnO}$, while the Gornja Tuzla slag bears a unique As-Sn-Sb signature. The total ore signature varies from $0.5 \mathrm{wt}$ per cent (slagged sherd 31a) to 22.8 wt per cent (slag 23).

All samples are dominated by newly-formed copper oxide-based compounds and copper metal, commonly followed by delafossite, spinels and leucite (Fig. 6), but also with sporadic occurrence of fayalite, pyroxene, olivine, wüstite and iscorite (Radivojević 2012, 226ff.). Since the co-occurrence of cuprite, delafossite and iron spinels dominates the slag samples, it appears that a partially oxidized atmosphere prevailed, which was sufficient to smelt copper (Elliott 1976). Thus, the redox conditions suggest that the overall gas atmosphere was slightly oxidizing/moderately reducing, which resulted in producing successfully copper metal and the formation of heterogeneous slag in the sites of Belovode, VinčaBelo Brdo and Gornja Tuzla.

Noteworthy here is the virtually 'slagless' smelting in Belovode and Pločnik, illustrated by the evidence in samples M6 and 52 (Fig. 7). They both contain copper metal phase and residual primary copper minerals (chalcocite and covellite); the former occurs as both primary (angular) and secondary (round) phase, indicating a smelting attempt. While Belovode M6 is significant as a find predating the earliest production evidence in the site of Belovode, sample 52 represents the only known evidence of metal extraction at this site, amongst dozens of documented copper metal artefacts (Radivojević 2006; Radivojević \& Kuzmanović-Cvetković forthcoming). However, both attempts appear to be only partially successful, due to the fact that samples were not molten throughout. Also, no slag seem to be generated from these attempts.

The striking microstructural similarity of slag samples from the sites of Belovode, Vinča and Gornja Tuzla suggests similar technological principle of smelting in these sites, despite the fact that the smelting events were separated for up to six centuries. Another unifying point for these samples is the choice of ores, indicated by ore fingerprints in each of the glassy slag matrices (Table 2). The three ternary diagrams illustrate the compositionally closest correlation of ore signature from the slag glass composition with the potential ores used for metal making (Figs. 8-10). The geological ores matched on these diagrams show the closest compositional correspondence with the combination of metal oxides in the slag samples.

For Belovode samples, the ternary cluster $\mathrm{K}_{2} \mathrm{O}$ $\mathrm{CaO}-\mathrm{MnO}$ was used to demonstrate the difference between the ore and the fuel ash signature (Fig. 8); this is because the lime readings in Belovode slag were too high to be solely due to the fuel ash intake. Indeed, the alignment of readings along the $\mathrm{K}_{2} \mathrm{O}-\mathrm{CaO}$ axis presents a potential fuel ash signature (beech ash data after Jackson \& Smedley 2004, 39, table 4), while the strong cluster of a selection of glassy matrix data along the $\mathrm{CaO}-\mathrm{MnO}$ axis demonstrates the use of manganese-rich black-and-green copper minerals. The signature of the slag sample Vinča 79, besides the significant manganese intake (Table 2), also includes increased iron and phosphorus concentrations, which closely match the composition of blue/green phosphate vivianite $\left(\mathrm{Fe}_{3}\left(\mathrm{PO}_{4}\right)_{2} \cdot 8 \mathrm{H}_{2} \mathrm{O}\right)$ (Fig. 9). Hence, the likely combination of ores smelted at this site for this particular event could have been a mix of manganeserich black-and-green copper minerals and blue/green vivianite; the composition of Vinča 91 slag matrix, on the other hand, indicates the use of the former type of ore only. In the site of Gornja Tuzla, the slag glass matrix plots near the projection of secondary minerals of the phosphates/arsenates family such as scorodite $\left(\mathrm{FeAsO}{ }_{4} \cdot 2 \mathrm{H}_{2} \mathrm{O}\right)$, strengite $\left(\mathrm{FePO}_{4} \cdot 2 \mathrm{H}_{2} \mathrm{O}\right)$ and arthurite $\left(\mathrm{CuFe}{ }_{2}\left(\mathrm{AsO}_{4}, \mathrm{PO}_{4}, \mathrm{SO}_{4}\right)_{2} \bullet 4 \mathrm{H}_{2} \mathrm{O}\right)($ Fig. 10).

Whatever the exact minerals present in the ore charges that produced the slags samples analysed here, they most likely possessed strong colours in the range of green/blue (i.e. vivianite, arthurite, apatite, scorodite) and violet (i.e. strengite), in addition to black and green manganese-rich malachite (Belovode and Vinča only). These brightly coloured minerals 

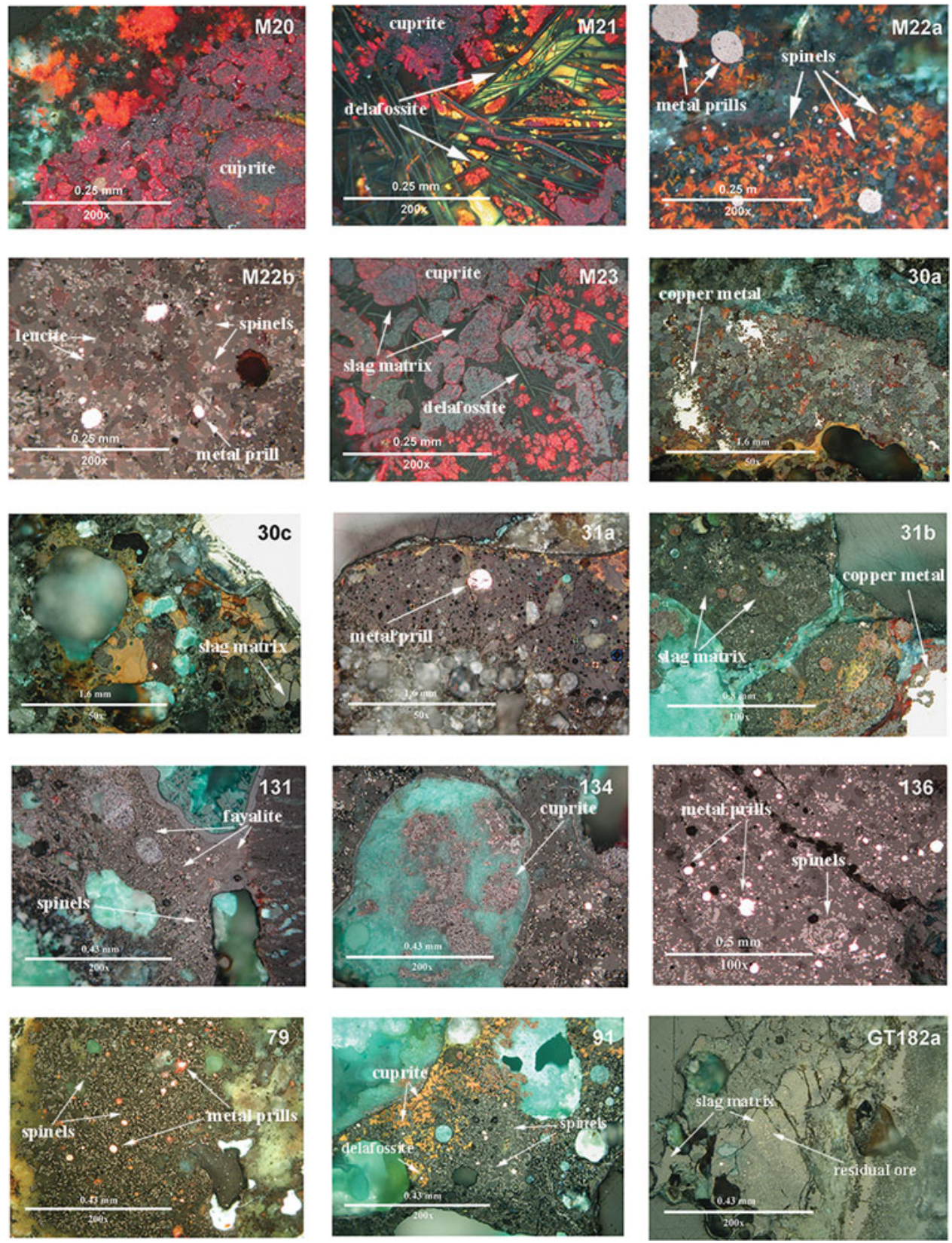

Figure 6. (Colour online) Microstructures of all free slag and slagged sherd samples with representative phases indicated as a guidance. All micrographs are taken under cross polarized light and contain sample number in top right corner. Belovode M20, M21, M22a, M22b, M23, 30a, 30c, 31a, 31b, 131, 134, 136; Vinča 79, 91; Gornja Tuzla 182a.

appear to have been collected by the Belovode and Vinča ore prospectors in paragenesis with darkcoloured manganese minerals. This may well have been the case for Gornja Tuzla, too. For instance, scorodite is the most common weathered mineral originating from the primary arsenic ore, arsenopyrite. Interestingly, the weathering of arsenopyrite results in green/blue scorodite and red/black goethite $(\mathrm{FeO}(\mathrm{OH}))($ Murciego et al. 2011, 594). Thus, the allure of green and dark/black minerals found together in the landscape could have been a decisive factor for collection by the smiths in all three sites, Belovode, Vinča and Gornja Tuzla.

A possible source for all these minerals in paragenesis with copper and iron ores is the Bor district in eastern Serbia, which is not too far from the studied sites (Belovode being the closest at c. $50 \mathrm{~km}$ distance). It contains massive sulphide deposits of 

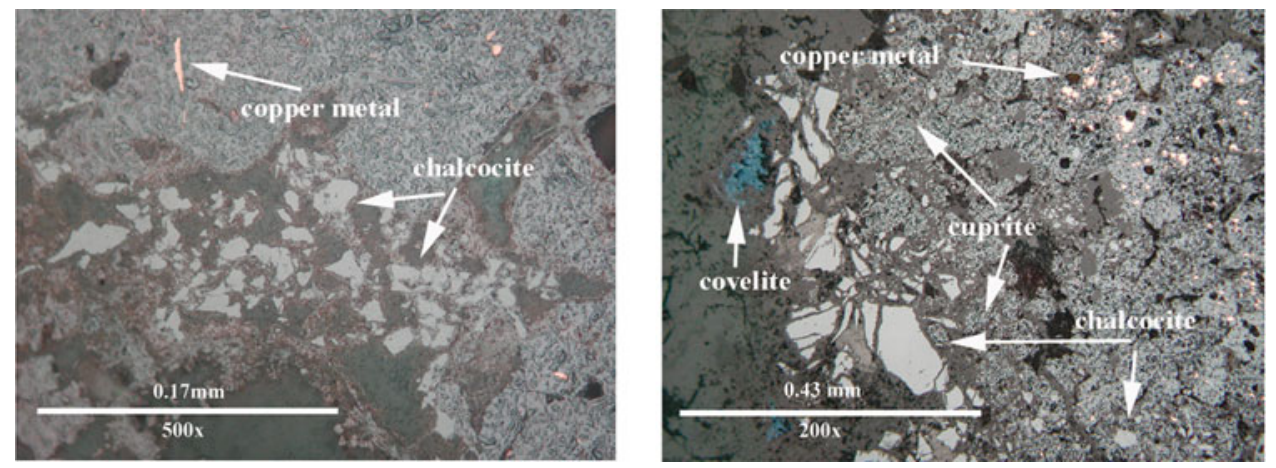

Figure 7. (Colour online) (Left) Photomicrograph of Belovode M6 under plane polarized light. Note the copper metal droplets embedded in cuprite (grey) and the partially decomposed chalcocite (light grey). (Right) Photomicrograph of Pločnik 52 under plane polarized light. Note the blocky and round chalcocite, besides, copper metal, cuprite and covellite.

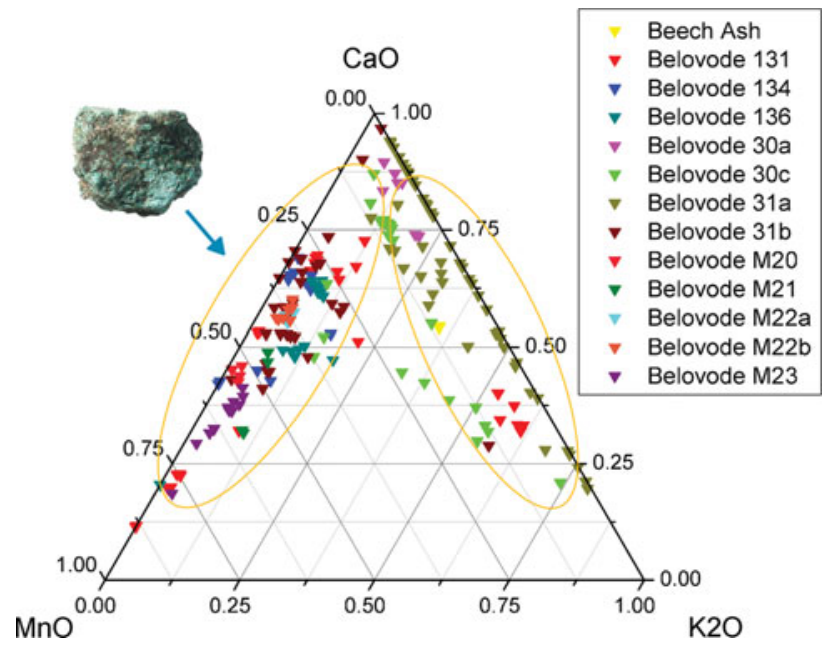

Figure 8. (Colour online) The $\mathrm{K} 2 \mathrm{O}-\mathrm{CaO}-\mathrm{MnO}$ plot of slag matrices in Belovode production evidence against the beech ash composition from Jackson and Smedley (2004, 39, table 4), including data published in Radivojević et al., 2010 (labelled with M). Distinctive clustering of data along the lime-potash (right ellipse) and lime-manganese (left ellipse) axes indicate fuel and ore contamination respectively. The mineral image stands for a typical representative of the black and green kind of ores smelted in Belovode.

cupreous pyrite, with rich primary and secondary copper minerals (Janković 1990; Sillitoe 1983) and polymetallic enrichments that makes the occurrence of scorodite and strengite, and other phosphates such as apatite and vivianite, very likely.

The allure of green and dark/black minerals could, therefore, have represented a decisive factor in selecting these coloured-coded ores for early metal extraction. Although it is not clear from the analyses whether black and green minerals were selected separately or as a mixed ore, the conclusion that emerges is the existence of a common knowledge concerning

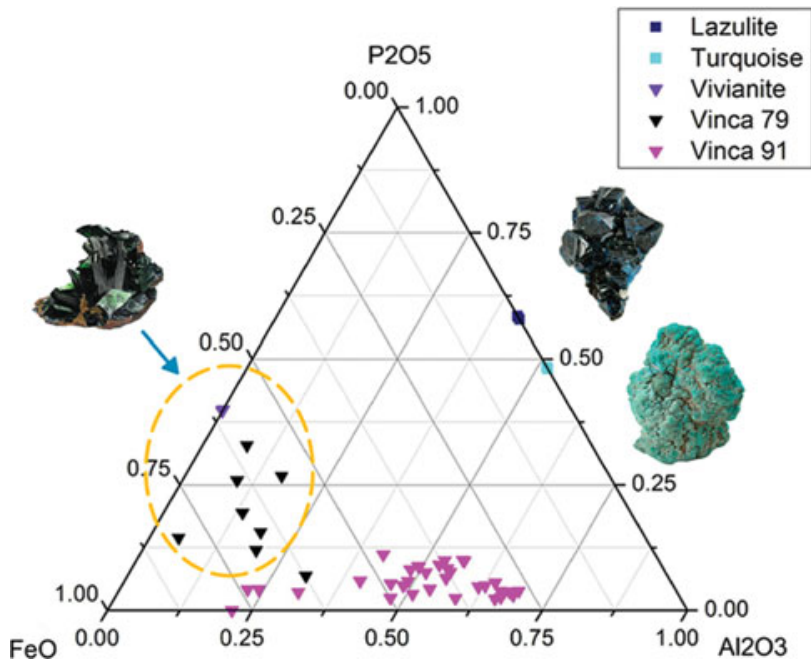

Figure 9. (Colour online) Ternary plot of Al2O3-P2O5-FeO values in glass matrices in Vinča 79 and 91 tested against the compositions of lazulite, turquoise and vivianite. The closest match to the composition of slag matrix is vivianite, a colourful hydrated iron phosphate. (Mineral images (C) Rob Lavinsky, www.irocks.com)

the suitability for smelting of distinctively coloured mixed minerals, as opposed to the uniformly green pure malachite selected at the same time for bead making (Radivojević 2012, 306; Radivojević et al. 2010). It is, however, not argued here that the pure green malachite was not used for smelting as well, but rather that the black and green minerals were intentionally selected for metal making in the sites of Belovode, Vinča and Gornja Tuzla, for more than half a millennium, as a sole or a combined ore charge. The colour factor emerges as particularly important in the light of the earliest tin bronze artefact discovered at the site of Pločnik (Radivojević et al. 2013). The hereditary selection and experimentation with the 
Table 2. SEM-EDS compositional data for glassy matrices in the metal production evidence from the sites of Belovode, Vinča and Gornja Tuzla, normalised to 100\% (together with Belovode evidence already published in Radivojević et al., 2010, labels beginning with M). Additional lines at the bottom include the typical Vinča ceramic composition, based on measurements from all three sites. All values are given as averages and sample standard deviation (bdl = below detection limit).

\begin{tabular}{|c|c|c|c|c|c|c|c|c|c|c|c|c|c|c|c|c|c|c|}
\hline & $\mathrm{Na} 2 \mathrm{O}$ & $\mathrm{MgO}$ & $\mathrm{Al} 2 \mathrm{O} 3$ & $\mathrm{SiO} 2$ & $\mathrm{P} 2 \mathrm{O} 5$ & $\mathrm{SO} 3$ & $\mathrm{~K} 2 \mathrm{O}$ & $\mathrm{CaO}$ & $\mathrm{TiO} 2$ & $\mathrm{MnO}$ & $\mathrm{FeO}$ & $\mathrm{CoO}$ & $\mathrm{NiO}$ & $\mathrm{CuO}$ & $\mathrm{ZnO}$ & As2O3 & $\mathrm{SnO} 2$ & $\mathrm{Sb} 2 \mathrm{O} 3$ \\
\hline & $\mathrm{wt} \%$ & $\mathrm{wt} \%$ & wt $\%$ & $\mathrm{wt} \%$ & $\mathrm{wt} \%$ & $\mathrm{wt} \%$ & $\mathrm{wt} \%$ & $\mathrm{wt} \%$ & wt $\%$ & $\mathrm{wt} \%$ & $\mathrm{wt} \%$ & $\mathrm{wt} \%$ & $\mathrm{wt} \%$ & $\mathrm{wt} \%$ & $\mathrm{wt} \%$ & $\mathrm{wt} \%$ & $\mathrm{wt} \%$ & $\mathrm{wt} \%$ \\
\hline Belovode M20 slag matrix & 1.1 & 2.5 & 3.9 & 40.6 & 3.9 & bdl & 1.0 & 17.3 & bdl & 18.5 & 4.0 & 0.2 & bdl & 3.9 & 3.2 & bdl & bdl & bdl \\
\hline s M20 & 0.2 & 1.0 & 1.9 & 5.1 & 1.4 & 0.0 & 0.4 & 1.2 & 0.0 & 1.4 & 0.9 & 0.5 & 0.0 & 2.1 & 2.0 & 0.0 & 0.0 & 0.0 \\
\hline Belovode M21 slag matrix & 0.7 & 1.4 & 6.0 & 40.2 & 4.1 & bdl & 2.3 & 12.3 & bdl & 13.8 & 11.9 & bdl & bdl & 4.3 & 3.1 & bdl & bdl & bdl \\
\hline$s$ M21 & 0.5 & 0.2 & 0.5 & 0.9 & 0.3 & 0.0 & 0.3 & 4.3 & 0.0 & 0.3 & 4.0 & 0.0 & 0.0 & 2.6 & 0.2 & 0.0 & 0.0 & 0.0 \\
\hline Belovode M22a slag matrix & 0.7 & 3.1 & 6.4 & 36.1 & 5.9 & bdl & 2.1 & 20.7 & 0.3 & 12.3 & 4.2 & 0.7 & bdl & 5.7 & 1.7 & bdl & bdl & bdl \\
\hline s M22a & 0.8 & 0.3 & 0.8 & 1.0 & 0.5 & 0.0 & 0.3 & 2.8 & 0.3 & 1.3 & 0.5 & 0.1 & 0.0 & 3.6 & 0.0 & 0.0 & 0.0 & 0.0 \\
\hline Belovode M22b slag matrix & 0.9 & 2.9 & 5.7 & 35.3 & 5.7 & bdl & 1.9 & 22.2 & 0.3 & 13.1 & 5.5 & 0.5 & bdl & 4.1 & 1.9 & bdl & bdl & bdl \\
\hline$s M 22 b$ & 0.1 & 0.1 & 0.5 & 1.1 & 0.6 & 0.0 & 0.3 & 0.6 & 0.2 & 1.0 & 0.7 & 0.4 & 0.0 & 0.9 & 0.3 & 0.0 & 0.0 & 0.0 \\
\hline Belovode M23 slag matrix & bdl & 1.4 & 7.5 & 40.4 & 2.2 & bdl & 1.4 & 10.9 & bdl & 17.1 & 6.7 & 1.4 & bdl & 6.9 & 4.2 & bdl & bdl & bdl \\
\hline$s \mathrm{~s} 23$ & 0.0 & 0.2 & 0.5 & 1.5 & 0.4 & 0.0 & 0.4 & 2.1 & 0.1 & 1.8 & 1.6 & 0.3 & 0.0 & 1.3 & 0.6 & 0.0 & 0.0 & 0.0 \\
\hline Belovode 30a slag matrix & bdl & 2.9 & 8.9 & 38.5 & 1.4 & bdl & 3.9 & 23.0 & 0.6 & 1.1 & 6.4 & bdl & bdl & 13.2 & 0.1 & bdl & bdl & bdl \\
\hline$s 30 a$ & 0.0 & 1.3 & 2.4 & 2.1 & 1.5 & 0.0 & 2.2 & 4.3 & 0.3 & 0.7 & 2.3 & 0.0 & 0.0 & 5.3 & 0.3 & 0.0 & 0.0 & 0.0 \\
\hline Belovode 30c slag matrix & bdl & 2.5 & 9.8 & 40.1 & 1.7 & bdl & 3.6 & 12.5 & 0.5 & 2.0 & 5.6 & 0.1 & bdl & 21.2 & 0.4 & bdl & bdl & bdl \\
\hline$s 30 c$ & 0.0 & 1.0 & 2.8 & 4.2 & 1.6 & 0.0 & 1.3 & 7.9 & 0.3 & 1.0 & 2.5 & 0.2 & 0.0 & 7.3 & 0.3 & 0.0 & 0.0 & 0.0 \\
\hline Belovode 31a slag matrix & 1.8 & 1.7 & 16.3 & 50.1 & 1.4 & bdl & 3.0 & 7.9 & 0.7 & 0.4 & 7.5 & bdl & bdl & 9.0 & 0.1 & bdl & bdl & bdl \\
\hline s 31a & 1.4 & 1.1 & 5.6 & 6.2 & 1.9 & 0.0 & 1.5 & 4.7 & 0.5 & 0.8 & 3.3 & 0.1 & 0.0 & 8.2 & 0.2 & 0.0 & 0.0 & 0.0 \\
\hline Belovode $31 \mathrm{~b}$ slag matrix & 0.8 & 1.6 & 6.0 & 40.4 & 3.9 & bdl & 1.8 & 15.0 & 0.3 & 8.4 & 12.7 & 0.5 & bdl & 7.3 & 1.4 & bdl & bdl & bdl \\
\hline$s 31 b$ & 0.7 & 0.8 & 2.6 & 7.4 & 1.6 & 0.0 & 1.2 & 6.5 & 0.3 & 5.2 & 4.4 & 0.4 & 0.0 & 14.2 & 0.9 & 0.0 & 0.0 & 0.0 \\
\hline Belovode 131 slag matrix & 0.1 & 1.7 & 8.9 & 46.8 & 4.3 & 0.0 & 1.7 & 8.6 & 0.4 & 7.1 & 17.0 & 0.2 & bdl & 2.6 & 0.6 & bdl & bdl & bdl \\
\hline$s 131$ & 0.4 & 1.6 & 2.9 & 9.0 & 1.6 & 0.0 & 1.2 & 6.4 & 0.2 & 6.8 & 9.2 & 0.2 & 0.0 & 3.9 & 0.7 & 0.0 & 0.0 & 0.0 \\
\hline Belovode 134 slag matrix & 0.9 & 1.9 & 7.3 & 41.6 & 3.5 & 0.3 & 0.9 & 13.6 & 0.2 & 7.4 & 10.1 & 0.3 & bdl & 10.9 & 1.1 & bdl & bdl & bdl \\
\hline s 134 & 0.7 & 1.0 & 1.4 & 4.7 & 0.8 & 0.5 & 0.8 & 7.7 & 0.2 & 2.7 & 4.7 & 0.3 & 0.0 & 12.0 & 0.5 & 0.0 & 0.0 & 0.0 \\
\hline Belovode 136 slag matrix & 0.5 & 1.6 & 6.9 & 36.4 & 3.2 & bdl & 2.5 & 16.8 & 0.2 & 9.8 & 12.0 & 0.7 & bdl & 7.5 & 1.8 & bdl & bdl & bdl \\
\hline s 136 & 0.4 & 0.4 & 0.6 & 4.3 & 0.6 & 0.0 & 1.0 & 6.2 & 0.2 & 0.4 & 7.6 & 0.3 & 0.1 & 8.0 & 0.4 & 0.0 & 0.0 & 0.0 \\
\hline Vinča 79 slag matrix & bdl & 1.0 & 5.0 & 41.9 & 6.5 & bdl & 5.6 & 5.5 & 0.1 & 1.6 & 21.8 & 0.1 & bdl & 10.8 & 0.1 & bdl & bdl & bdl \\
\hline$s 79$ & 0.0 & 0.2 & 2.5 & 4.5 & 3.1 & 0.0 & 4.1 & 3.1 & 0.2 & 0.3 & 3.0 & 0.2 & 0.0 & 3.7 & 0.2 & 0.0 & 0.0 & 0.0 \\
\hline Vinča 91 slag matrix & 0.2 & 4.3 & 12.0 & 49.2 & 1.3 & bdl & 3.7 & 5.2 & 0.5 & 2.8 & 9.5 & 0.1 & bdl & 10.0 & 1.0 & bdl & bdl & bdl \\
\hline s 91 & 0.4 & 1.7 & 2.8 & 3.9 & 0.5 & 0.0 & 3.3 & 5.5 & 0.4 & 2.6 & 3.4 & 0.2 & 0.0 & 4.6 & 0.4 & 0.0 & 0.0 & 0.0 \\
\hline GT 182a slag matrix & 1.1 & 4.7 & 11.6 & 41.9 & 3.3 & bdl & 2.4 & 14.4 & 0.5 & 0.1 & 7.9 & bdl & 0.1 & 10.1 & bdl & 1.5 & 0.1 & 0.2 \\
\hline s GT 182 & 1.2 & 3.0 & 4.2 & 8.5 & 1.1 & 0.1 & 1.8 & 6.7 & 0.3 & 0.2 & 2.9 & 0.1 & 0.1 & 8.4 & 0.1 & 0.9 & 0.3 & 0.4 \\
\hline average Vinča ceramic & 1.4 & 1.9 & 16.0 & 65.8 & 0.6 & bdl & 3.3 & 2.5 & 0.8 & bdl & 7.5 & bdl & bdl & bdl & $\mathrm{bdl}$ & bdl & bdl & bdl \\
\hline$s$ & 0.7 & 0.6 & 0.6 & 2.6 & 0.5 & 0.0 & 0.4 & 1.3 & 0.1 & 0.0 & 1.3 & 0.0 & 0.0 & 0.0 & 0.0 & 0.0 & 0.0 & 0.0 \\
\hline
\end{tabular}




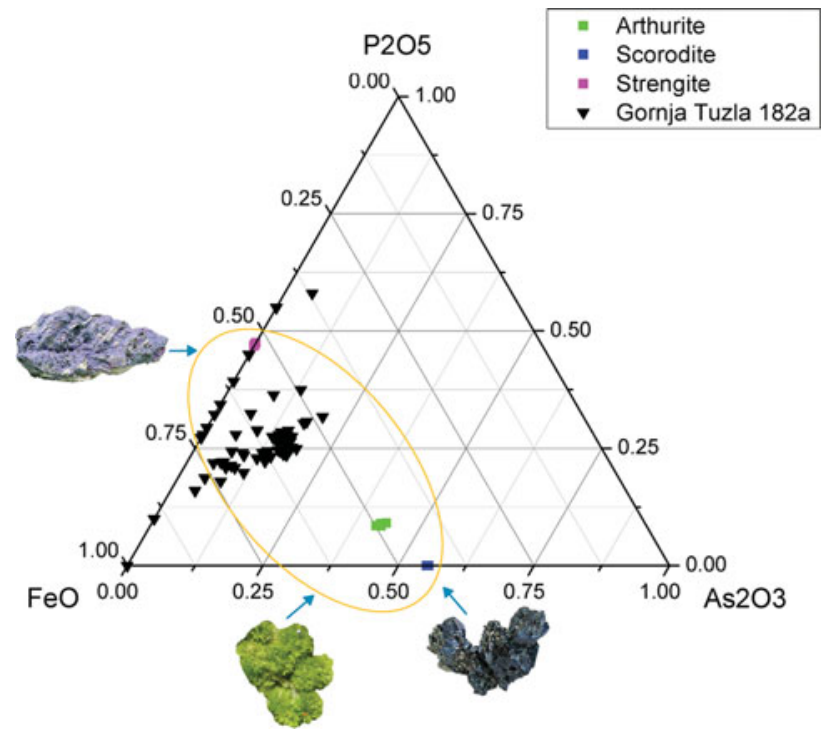

Figure 10. (Colour online) The As2O3-P2O5-FeO plot of slag matrices in GT 182a and GT 194 against mineral compositions of arthurite (ㄷ) Leon Hupperichs), scorodite (C) Rob Lavinsky, www.irocks.com) and strengite (C) www.fabreminerals.com). Yellow ellipse around GT 182a values indicates that the smelting charge possibly included a mixture of these minerals, or potentially phosphoroscorodite $(\mathrm{Fe}(\mathrm{As}, \mathrm{P}) \mathrm{O} 4 \cdot 2 \mathrm{H} 2 \mathrm{O})$, an intermediate phase between scorodite and strengite.

properties of tainted, black-and-green copper-tin rich ores (as in stannite: $\mathrm{Cu}_{2}(\mathrm{Fe}, \mathrm{Zn}) \mathrm{SnS}_{4}$ ) is argued as a potential driving factor for the invention of tin bronze metallurgy in the fifth-millennium вс Balkans.

\section{Chance favours the prepared mind}

Macroscopic, microstructural and compositional analyses have revealed a particular preference for blackand-green copper minerals by prehistoric communities inhabiting seven different Balkan settlements between c. 6200 and c. 4400 BC. There is no doubt that such a preference must have been shaped by the easy access to abundant copper deposits in the Balkans, as the Early Neolithic communities are known to have utilized these sources for bead making from pure green malachite (Radivojević 2012, 399; Srejović 1972, 146). Nonetheless, the only other type of copper mineral singled out from a plethora of available geological choices by the same communities was the black-andgreen manganese-rich one. This dual selection principle (pure and tainted minerals) also continues in the Vinča culture, as demonstrated by previous research (Radivojević et al. 2010, 2784ff.), implying that the decisions made towards their selection were guided by their colour as well as inherent knowledge of their material properties.

Despite the fact that the function of the manganese-rich copper minerals from the late seventh-/ mid sixth-millennium вс occupations at the sites of Lepenski Vir, Vlasac and Kolubara-Jaričište remains unclear, they would not have emerged as significant for the evolution of Balkan metallurgy had they not been encountered again around a millennium later in the context of the earliest copper-smelting activities at the sites of Belovode and Vinča. Although these manganese-rich minerals were apparently not smelted in the other two sites, Pločnik and Gornja Tuzla, the choice of smelted ores is assumed to have remained black and green. While the choice of black and green ores in Gornja Tuzla has already been mentioned above, the copper metal droplet from Pločnik (sample 52) was most possibly a product of heat-treating a mineral paragenesis of cuprite and copper sulphides, the latter of which stains the green mineral with dark inclusions (sample $72 \mathrm{~m}$ from the same site is the best comparable mineral example). Hence, the evolutionary trajectory of copper metallurgy in this part of Eurasia was shaped by the knowledge of material properties of black and green manganese-rich copper minerals, which was acquired during a millennium-long selection by the Neolithic communities in the Balkans prior to their smelting. The same selection practices imply that information about properties and location of these minerals was possibly culturally transmitted and part of the shared cultural and technological tradition. Although the mechanisms of transmission are not clear, the provenance analyses of the black and green manganese-rich minerals from Lepenski Vir, Vlasac, Kolubara-Jaričište and Belovode contribute to this argument by revealing their likely origin from the same (local) source (Radivojević 2012, 399ff.).

The black-and-green manganese-rich copper mineral was thus the techmeme of copper metallurgy in the Balkans. The knowledge of its properties appears hereditary; it mutated, varied, multiplied and descended with modification throughout almost two millennia. During at least the last six centuries of this period, the Vinča culture copper smiths were aware that black-and-green copper ores were suitable to produce metal under variable conditions of the smelt. The physical advantage of these particular type of ores was the nature of manganese oxide, which is known to facilitate the formation of a melt under lower operating temperatures than those required when, for instance, iron oxide is present in the system (Huebner 1969, 463, fig. 3; Heimann et al. 2001, 233). Therefore, the advantageous chemical-physical properties of 
manganese oxides enabled an easier reduction of copper ores to metal and slags within less-controlled smelting environments.

It may be concluded that the physical environment of the observed copper smelting process determined its success and accordingly reinforced the preference for black and green ores among the Vinča culture smiths. Such understanding was crucial for a successful transformation of ore to metal, and was preceded by another transformation, that from the perception of black and green copper minerals into black and green copper ores.

When it comes to the three stages of metallurgical invention, the gestation period is represented by the earliest finds of manganese-rich copper minerals in the sites of Lepenski Vir, Vlasac and KolubaraJaričište. At this stage, the invention did not have an identifiable form, as we do not know what their purpose was at the time; however, an awareness of a particular capability of these black and green minerals could have started developing. The cradle period here refers to a gap between the Early Neolithic (ending at c. 5500 BC) and the post-5000 Bс Vinča culture communities. This is the time when an invention has a pre-mature anatomy: i.e. the copper metal extraction could have happened, although not in a capacity encountered in, for instance, the smelting slags from Belovode. Two copper metal droplets (M6 and 52: Fig. 7) possibly fit this description. Belovode M6 is particularly significant as it precedes the 'slagging' smelting by a few decades, and implies that this stage of invention evolution was most likely represented by a series of experimentation in a trial-and-error process. The copper-smelting evidence from c. 5000 вс demonstrates that Belovode copper smiths eventually developed an understanding of the benefits of (limited) slag-forming smelting. This is illustrated by the smelting recipe that was successfully replicated without extreme variations in this site, thus marking the maturation stage. The technologically similar smelting principle in the Vinča and Gornja Tuzla slag indicates its replication during c. 600 years and marks the innovation stage in the Vinča culture metallurgy (Fig. 11).

The reproduction of the metal-making recipe across the Vinča culture sites is indicated by adoption and adaptation processes. The latter is represented by the variable choice of ores which, despite different composition, kept the same black-and-green colour code. The best manifestation of the transmission of metallurgical knowledge across the Balkans is the $c$. 4.7 tonnes of extant metal implements known to circulate this region during the fifth millennium $\mathrm{BC}$; at least a portion of these could be ascribed to the replication of the smelting recipe observed in this study.

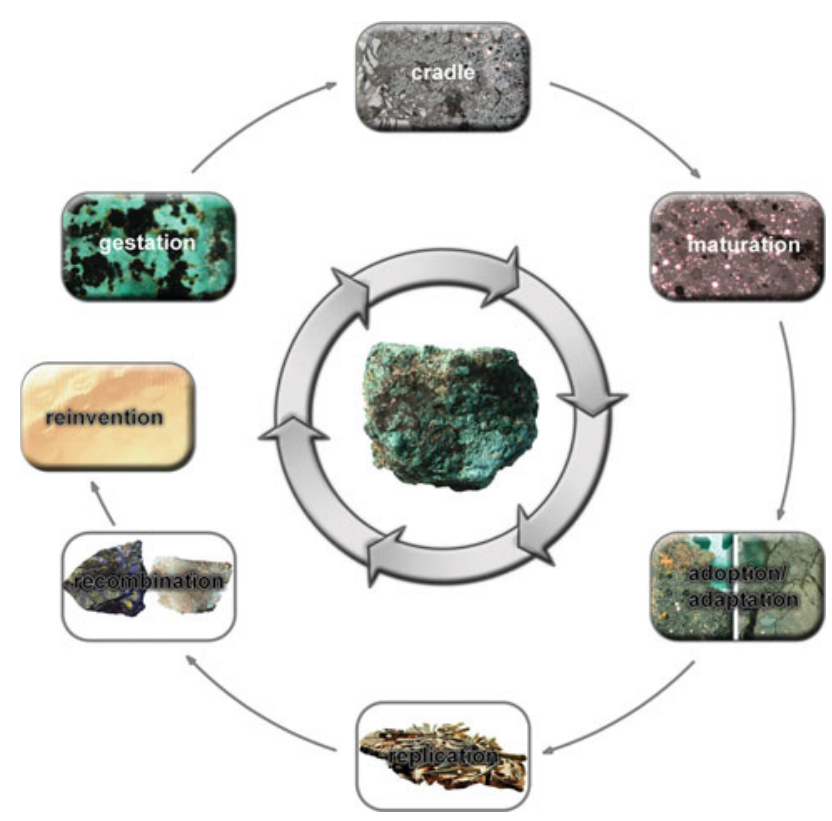

Figure 11. (Colour online) Schematic representation of the invention and innovation stages in Balkan copper metallurgy leading into another cycle of (re)invention of tin bronzes. The underlying technological meme is the black and green mineral/ore. (Replication stage image (C) $K$. Dimitrov; recombination stage image (left) (C) Kō Collection of minerals, Kyushu University, Japan.)

The black-and-green ores remain a smelting 'recipe' ingredient prone to the greatest variation and creativity within an otherwise consistent smelting environment. The process slowly evolved into smelting of more complex copper ores only towards the end of the Vinča culture, as attested by the Gornja Tuzla example, containing small but significant amounts of arsenic, antimony and tin. This trajectory towards 'natural alloys' is illustrated by the occurrence of complex tin bronzes in the late Vinča culture, which can also be linked to the use of colourful complex coppertin-bearing ores (Radivojević et al. 2013). The invention of tin bronzes in the Balkans hence appears as intimately related to the invention of copper smelting, and is as such embedded in the evolutionary potential of black-and-green ores, the techmeme of the early copper metallurgy in this region.

\section{The invention of metallurgy}

Detailed microanalytical study of the copper mineral and archaeometallurgical assemblage from the late seventh- to the late fifth-millennium $\mathrm{BC}$ settlements portrays an unprecedented image of the earliest evolution of metallurgy in Eurasia. A set of 
presented microstructural and compositional analyses established a methodological example for investigating the life cycle of metallurgical invention down to the re-invention stage, all underlined by a distinctive technological colour-coded core trait culturally transmitted for almost two millennia. This micro-glance into the alchemy of mineral-to-ore transformation addressed the emergence of pyrometallurgy in Eurasia beyond the restless quest for the origins of metallurgy, and dismantled its components by addressing the how and why of such a development.

As this study argues, the knowledge of metal extraction in the Balkans is a result of an evolutionary potential of black-and-green minerals, whose history of selection goes back to the late seventh/early sixth millennium вс. The invention of metallurgy required appropriate interconnections made by individuals between their environmental surroundings, social practices and the physical properties of raw materials. It was not only about the very (technical) moment of turning mineral into ore, but also about other components of the invention process that facilitated its maturation in the hands of the inventor.

These interconnections were most likely forged through a deep and enduring preference for colour aesthetics whose full expression in the Balkans culminated in the fifth millennium вс (Chapman 2002; 2007; 2011). Such aesthetic preference can be seen in the outstanding degree of proficiency for decorating vessels with gold in the Varna I cemetery (Ivanov 1988) or exceptional painting techniques on graphite-decorated pottery of the Karanovo-Gumelniţa-Kodžadermen VI cultural complex (Todorova \& Vajsov 1993). There is also a notable preference for black in the Vinča culture (Chapman 2006), potentially one of the reasons for experimenting with black-and-green ores.

The fact that this unique techmeme has no parallel at the time marks its evolution in this region as strongly independent in comparison to similar and (almost) contemporary metallurgical developments worldwide. This study, however, does not claim that the very thought of metal extraction was conceived in the Balkans. Pyrometallurgy, like any other idea, had multiple origins, but it was the Vinča culture population that advanced this idea and emerged as the first metal-producing and -consuming society in western Eurasia. It means that social institutions to support the production, logistics and markets for metal products were already in place. Although the archaeological record does not clearly demonstrate why such institutions were established, and what were the underlying mechanisms, some clues may certainly be found in the preference for shiny and colourful objects in the fifth-millennium вс Balkans. It could be that the em- phasis on brilliance in material culture rendered metal production practical and metal artefacts desirable.

The consistency of metal-producing technology throughout the observed evidence from Belovode, Vinča and Gornja Tuzla speaks of a knowledge that was probably learned as a traditional 'package' by same-gender offspring or an apprentice (cf. Shennan \& Steele 1999). However, although (traditional) environmental learning of metallurgical skills might have taken place in the initial phase of practising metallurgy, the pace of its spread was probably dictated by forces of biased transmission (cf. Henrich 2001). Henrich (2001: 1009) argues that all individuals, regardless of their economic position and exposure, are equally likely to adopt an innovation early; however, their position in a society, such as high status, will be crucial for dictating the pace of an innovation transmission.

The archaeological record of the social role of Vinča culture copper smiths is as yet not well known. It is worth mentioning that the identified metal workshops from the sites of Belovode, Vinča or Gornja Tuzla do not contain unusual archaeological materials, as ceramic material and figurines from these features do not stand out in typology, or the size of the assemblage (Radivojević 2012, 424). Thus, it may be assumed that copper smiths were an integral part of the Vinča culture society, although the scale of their occupation (full/part-time) is currently difficult to estimate. Furthermore, nothing in their known material status implies that they had a higher-ranked position in a society, which makes them unlikely candidates to dictate the spread of metallurgical innovation.

It is therefore assumed here that metalconsuming higher-ranked individuals acted as one of the major forces for the rapid spread and adoption of metallurgical innovation across the Balkans in the fifth millennium вс. The demands of higher-ranked individuals paired with accumulation of learned skills in a metal-producing community could have stimulated another cycle of inventions in metallurgy, which introduced gold, tin bronze, lead and silver in the mid to late fifth-millennium вс exchange networks, although in a limited mode of production (Radivojević et al. 2013, 1041-2). An important conclusion following the emergence of this polymetallic horizon is that the understanding of material properties of metals other than copper, such as tin-bronze or gold, implies that various technological solutions were actively pursued (see Leusch et al., this volume), marking the horizon of their emergence as polytechnological as much as polymetallic.

The evolutionary trajectory of the Vinča culture metallurgy emerges as a regional phenomenon during 
the course of the fifth millennium вс. The continual production of metal implements in this period demonstrates that the learning network of Vinča metal smiths eventually exceeded its initial size and remained resistant to the collapse of the Vinča culture (mid fifth millennium вс). It expanded beyond the traditional concept of a 'culture' and followed its own dynamics of functioning, very much resembling the phenomenon of the Balkan-Carpathian metallurgical province (cf. Chernykh 1978). Given the current state of evidence, the inception of the fifth-millennium вс Balkan network of copper smiths is to be sought in the invention of metal extraction within the Vinča culture, as revealed here under the lens of a microscope. Analytical results presented above demonstrated the strength of a materials science approach in studying technological invention, and brought us a step further in understanding the phenomenon of metallurgy invention in western Eurasia.

\section{Acknowledgements}

The study is part of the author's PhD thesis, conducted at the UCL Institute of Archaeology and supervised by Professors Thilo Rehren, Stephen Shennan and Ernst Pernicka, to whom I remain indebted for excellent guidance. This research was kindly supported by the EPSRC's Dorothy Hodgkin Postgraduate Award, Serbian Ministries of Culture, Science, and Youth and Sports, Open Society Foundations and Freeport McMoRan Copper and Gold Foundation through IAMS, the Institute for Archaeo-Metallurgical Studies in London. The work on this research is continued under the larger collaborative project kindly supported by the UK AHRC, titled 'The Rise of Metallurgy in Eurasia' (No. AH/J001406/1), and directed by Prof. Thilo Rehren. I am most grateful to Julka Kuzmanović.Cvetković., Duško Šljivar, Nenad Tasić., Mirjana Blagojević., Andrijana Pravidur and Slaviša Perić for generous access to materials and Kevin Reeves and Ljiljana Radivojević for technical support. I am also grateful to Ron Jacobson, Rob Lavinsky, Leon Hupperichs and Jordi Fabre for kind permission to use mineral images. Comments by B. Roberts and two anonymous reviewers helped me to better situate this research; any remaining shortcomings are mine.

\section{Supplementary material}

To view supplementary material for this article, please visit http:/ / dx.doi.org/10.1017/S0959774314001097

M. Radivojević University College London Institute of Archaeology 31-34 Gordon Square London
WC1H OPY

UK

Email:m.radivojevic@ucl.ac.uk

\section{References}

Basalla, G., 1988. The Evolution of Technology. Cambridge: Cambridge University Press.

Borić, D., 2009. Absolute dating of metallurgical innovations in the Vinča culture of the Balkans, in Metals and Societies. Studies in honour of Barbara S. Ottaway, eds. T.L. Kienlin \& B.W. Roberts. Bonn: Dr. Rudolf Habelt, 191-245.

Borić, D. \& V. Dimitrijević, 2007. Absolute chronology and stratigraphy of Lepenski Vir. Starinar 57, 9-55.

Borić, D., C. French \& V. Dimitrijević, 2008. Vlasac revisited: formation processes, stratigraphy and dating. Documenta Praehistorica 35, 261-87.

Carlson, W.B., 2000. Invention and evolution, in Technological Innovation as an Evolutionary Process, ed. J. Ziman. Cambridge: Cambridge University Press, 137-58.

Cavalli-Sforza, L.L. \& M.W. Feldman, 1981. Cultural Transmission and Evolution: A Quantitative Approach. Princeton (NJ): Princeton University Press.

Chapman, J., 2002. Colourful prehistories: the problem with the Berlin and Kay paradigm, in Colouring the Past. The Significance of Colour in Archaeological Research, eds. A. Jones \& G. MacGregor. Oxford: Berg, 45-72.

Chapman, J., 2006. Dark burnished ware as a sign: ethnicity, aesthetics and categories in the later Neolithic of the central Balkans, in Homage to Milutin Garašanin, eds. N. Tasić \& C. Grozdanov. Belgrade: Serbian Academy of Sciences and Arts and Macedonian Academy of Sciences and Arts, 295-308.

Chapman, J., 2007. The elaboration of an aesthetic of brilliance and colour in the climax Copper Age, in Stephanos Aristeios. Archäologische Forschungen zwischen Nil und Istros. Festschrift für Stefan Hiller zum 65. Geburtstag, eds. F. Lang, C. Reinholdt \& J. Weilhartner. Vienna: Phoibos Verlag, 65-74.

Chapman, J., 2011. Enchantment and enchainment in later Balkan prehistory: towards an aesthetic of precision and geometric order, in The Dynamics of Neolithisation in Europe. Studies in Honour of Andrew Sherratt, eds. A. Hadjikoumis, E. Robinson \& S. Viner. Oxford: Oxbow Books, 153-76.

Chernykh, E.N., 1978. Gornoe Delo i Metallurgiya v Dreioneishei Bolgarii. Sofia: Bolgarskoi Akademii Nauk.

David, P.A., 2000. Path dependence and varieties of learning in the evolution of technological practice, in Technological Innovation as an Evolutionary Process, ed. J. Ziman. Cambridge: Cambridge University Press, 118-34.

Dawkins, R., 1976. The Selfish Gene. Oxford: Oxford University Press.

Elliott, J.F., 1976. Phase relationships in the pyrometallurgy of copper. Metallurgical and Materials Transactions B. 
Process Metallurgy and Materials Processing Science 7, 17-33.

Fitzhugh, B., 2001. Risk and invention in human technological evolution. Journal of Anthropological Archaeology 20, 125-67.

Heimann, R.B., U. Kreher, I. Spazier \& G. Wetzel, 2001. Mineralogical and chemical investigations of bloomery slags from prehistoric (8th century BC to 4th century AD) iron production sites in upper and lower Lusatia, Germany. Archaeometry 43, 227-52.

Henrich, J., 2001. Cultural transmission and the diffusion of innovations: adoption dynamics indicate that biased cultural transmission is the predominate force in behavioral change. American Anthropologist 103, 9921013.

Henrich, J., 2010. The evolution of innovation-enhancing institutions, in Innovation in Cultural Systems. Contributions from Evolutionary Anthropology, eds. M.J. O'Brien \& S.J. Shennan. Cambridge (MA): MIT Press, 99-120.

Huebner, J., 1969. Stability relations of rodochrosite in the system manganese-carbon-oxygen. American Mineralogist 54, 457-81.

Ivanov, I., 1988. Die Ausgrabungen des Gräberfeldes von Varna, in Macht, Herrschaft und Gold: Das Gräberfeld von Varna und die Anfänge einer Neuen Europäischen Zivilisation, eds. A. Fol \& J. Lichardus. Saarbrücken: Moderne Galerie des Saarland-Museums, 49-66.

Jablonka, E. \& J. Ziman, 2000. Biological evolution: processes and phenomena, in Technological Innovation as an Evolutionary Process, ed. J. Ziman. Cambridge: Cambridge University Press, 13-26.

Jackson, C.M. \& J.W. Smedley, 2004. Medieval and postmedieval glass technology: melting characteristics of some glasses melted from vegetable ash and sand mixtures. Glass Technology 45, 36-42.

Janković, S., 1990. Types of copper deposits related to volcanic environment in the Bor district, Yugoslavia. Geologische Rundschau 79, 467-78.

Jewkes, J., D. Sawers \& R. Stillerman, 1969. The Sources of Invention (2nd edition). London: Macmillan.

Killick, D. \& T.R. Fenn, 2012. Archaeometallurgy: the study of preindustrial mining and metallurgy. Annual Review of Anthropology 41, 559-75.

Krause, R.A., 1985. The Clay Sleeps. Tuscaloosa (AL): University of Alabama Press.

Kuhn, T., 1962. The Structure of Scientific Revolutions. Chicago (IL): University of Chicago Press.

Lienhard, J.H., 2006. How Invention Begins. Oxford: Oxford University Press.

Martinón-Torres, M. \& Th. Rehren, 2008. Archaeology, History and Science: Integrating Approaches to Ancient Materials. Walnut Creek (CA): Left Coast Press.

Martinón-Torres, M. \& Th. Rehren, 2009. Post-medieval crucible production and distribution: a study of materials and materialities. Archaeometry 51, 49-74.

Mason, O.T., 1895. The Origins of Invention: A Study of Industry Among Primitive Peoples. London: Walter Scott, Ltd.
Murciego, A., E. Álvarez-Ayuso, E. Pellitero, et al., 2011. Study of arsenopyrite weathering products in mine wastes from abandoned tungsten and tin exploitations. Journal of Hazardous Materials 186, 590-601.

Murillo-Barroso, M. \& I. Montero- Ruíz, 2012. Copper ornaments in the Iberian Chalcolithic: technology versus social demand. Journal of Mediterranean Archaeology 25, 53-73.

O’Brien, M.J. \& R.L. Lyman, 2000. Applying Evolutionary Archaeology: A Systematic Approach. New York (NY): Kluwer Academic/Plenum Publishers.

O'Brien, M.J. \& S.J. Shennan (eds.), 2010a. Innovation in Cultural Systems. Contributions from Evolutionary Anthropology. Cambridge (MA): MIT Press.

O’Brien, M.J. \& S.J. Shennan, 2010b. Issues in anthropological studies of innovation, in Innovation in Cultural Systems. Contributions from Evolutionary Anthropology, eds. M.J. O’Brien \& S.J. Shennan. Cambridge (MA): MIT Press, 3-17.

Pernicka, E., F. Begemann, S. Schmitt-Strecker, H. Todorova \& I. Kuleff, 1997. Prehistoric copper in Bulgaria. Its composition and provenance. Eurasia Antiqua 3, 41180.

Powell, A., S. Shennan \& M.G. Thomas, 2009. Late pleistocene demography and the appearance of modern human behavior. Science 324, 1298-301.

Radivojević, M., 2006. A contribution to the typology and distribution of hammer axes of Pločnik type in southeast Europe (in Serbian). Journal of Serbian Archaeological Society 22, 211-24.

Radivojević, M., 2012. On the Origins of Metallurgy in Europe: Metal Production in the Vinča Culture. PhD thesis, Institute of Archaeology, University College London.

Radivojević, M. \& J. Kuzmanović-Cvetković, forthcoming. Copper minerals and archaeometallurgical materials from the Vinča culture sites of Belovode and Pločnik: overview of the evidence and new data. Starinar 64 .

Radivojević, M., Th. Rehren, J. Kuzmanović-Cvetković, M. Jovanović \& J.P. Northover, 2013. Tainted ores and the rise of tin bronze metallurgy, c. 6500 years ago. Antiquity 87, 1030-45.

Radivojević, M., Th. Rehren, E. Pernicka, D. Šljivar, M. Brauns \& D. Borić, 2010. On the origins of extractive metallurgy: new evidence from Europe. Journal of Archaeological Science 37, 2775-87.

Renfrew, C., 1978. The anatomy of innovation, in Social Organization and Settlement, eds. D. Green, C. Haselgrove \& M. Spriggs. (BAR International Series 47/1.) Oxford: British Archaeological Reports, 89-117.

Roberts, B. \& C.P. Thornton (eds.) 2014. Archaeometallurgy in Global Perspective. Methods and Syntheses. New York (NY): Springer.

Roberts, B.W., C.P. Thornton \& V.C. Pigott, 2009. Development of metallurgy in Eurasia. Antiquity 83, 101222.

Roux, V., 2003. A dynamic systems framework for studying technological change: application to the emergence of 
the potter's wheel in the southern Levant. Journal of Archaeological Method and Theory 10,1-30.

Ryndina, N., 2009. The potential of metallography in investigations of early objects made of copper and copperbased alloys. Historical Metallurgy 43, 1-18.

Shennan, S., 1989. Cultural transmission and cultural change, in What's New? A Closer Look at the Process of Innovation, eds. S.E. van der Leeuw \& R. Torrence. London: Unwin Hyman, 330-46.

Shennan, S., 2000. Population, culture history, and the dynamics of culture change. Current Anthropology 41, 811-35.

Shennan, S., 2001. Demography and cultural innovation: a model and its implications for the emergence of modern human culture. Cambridge Archaeological Journal $11,5-16$.

Shennan, S., 2002. Genes, Memes and Human History: Darwinian Archaeology and Cultural Evolution. London: Thames \& Hudson.

Shennan, S. \& J. Steele, 1999. Cultural learning in hominids: a behavioural ecological approach, in Mammalian Social Learning: Comparative and Ecological Perspectives, eds. H.O. Box \& K.R. Gibson. Cambridge: Cambridge University Press, 367-88.

Sillar, B. \& M.S. Tite, 2000. The challenge of 'technological choices' for materials science approaches in archaeology. Archaeometry 42, 2-20.

Sillitoe, R.H., 1983. Enargite-bearing massive sulfide deposits high in porphyry copper systems. Economic Geology 78, 348-52.

Srejović, D., 1972. Europe's First Monumental Sculpture: New Discoveries at Lepenski Vir. London: Thames \& Hudson.

Srejović, D. \& Z. Letica, 1970-1971. Vlasac field excavation diaries. Belgrade: Faculty of Philosophy.

Steward, J.H., 1955. Theory of Culture Change. The Methodology of Multilinear Evolution. Urbana (IL): University of Illinois Press.

Tite, M.S., V. Kilikoglou \& G. Veknis, 2001. Strength, toughness and thermal shock resistance of ancient ceramics, and their influence on technological choice. Archaeometry 45, 301-24.
Todorova, H. \& I. Vajsov, 1993. Novo-Kamennata Epokha v Bulgariya. Sofia: Nauka i Izkustvo.

Torrence, R. \& S.E. van der Leeuw, 1989. Introduction: what's new about innovation?, in What's New? A Closer look at the Process of Innovation, eds. S.E. van der Leeuw \& R. Torrence. London: Unwin Hyman, $1-15$.

van der Leeuw, S.E. \& R. Torrence (eds.) 1989. What's New? A Closer Look at the Process of Innovation. London: Unwin Hyman.

Vincenti, W.G., 2000. Real-world variation-selection in the evolution of technological form: historical examples, in Technological Innovation as an Evolutionary Process, ed. J. Ziman. Cambridge: Cambridge University Press, 174-89.

Weber, R.J., S. Dixon \& A.M. Llorente, 1993. Studying invention: the hand tool as a model system. Science, Technology, E Human Values 18, 480-505.

Wiener, N., 1993. Invention. The Care and Feeding of Ideas. Cambridge (MA): MIT Press.

Ziman, J., 2000. Evolutionary models for technological change, in Technological Innovation as an Evolutionary Process, ed. J. Ziman. Cambridge: Cambridge University Press, 3-12.

\section{Author biography}

Miljana Radivojević is an AHRC postdoctoral research associate in the 'Rise of Metallurgy in Eurasia' project (AH/J001406/1), hosted by the UCL Institute of Archaeology in London, UK. Her current research focus is on the beginnings of metallurgy in Eurasia, which combines fieldwork in Serbia and analytical work in the United Kingdom and Germany within a large international collaboration of eight institutions from these three countries. She has published on the technology of early copper production and recorded the world's earliest copper and tin bronze artefacts, using materials science methodology to address the origins of non-ferrous metallurgical activities. 